\title{
PENYULUHAN STRATEGI MERAIH PRESTASI DENGAN CERDAS DAN BERETIKA MASA KINI
}

\author{
${ }^{1}$ Ali Maddinsyah, ${ }^{2}$ Nasmal Hamda, ${ }^{3}$ Rahmi Hermawati \\ ${ }^{1}$ Dosen Pascasarjan Universitas Pamulang \\ ${ }^{2}$ Dosen Fakultas Keguruan Dan Ilmu Pendidikan Universitas Pamulang \\ ${ }^{3}$ Dosen Fakultas Ekonomi Universitas Pamulang \\ Email : ${ }^{1}$ alimaddinsyah@unpam.ac.id
}

\begin{abstract}
ABSTRAK
Tujuan yang ingin dicapai dalam kegiatan ini adalah untuk mengetahui sejauh mana keberhasilan penyuluhan penerapan strategi untuk meraih prestasi dengan cara cerdas dan beretika masa kini

Metode pelaksanaan dilakukan melalui metode klasikal dengan pendekatan diskusi/tanya jawab dan simulasi

Hasil kegiatan ini menjadikan para peserta dapat menyusun strategi untuk meraih prestasi dengan cara cerdas tanpa melupakan etika dan kesopanan, munculnya kesadaran akan keberhasilan mendapatkan masa depan yang baik.
\end{abstract}

\section{Kata Kunci : Prestasi, Cerdas, Etika.}

\section{PENDAHULUAN}

Keberadaan pondok pesantren saat ini sudah tidak bisa dipungkiri lagi manfaat nya, selain para santri dapat belajar materi umum, santri juga lebih dapat menguasai ilmu agama ketika mengikuti pembelajaran di pondok pesantren dengan syarat harus bisa hidup mandiri dan tidak tinggal dengan orang tua dalam kurun waktu tertentu, Pondok Pesantren Darul Ulum Pada awalnya Pondok Pesantren Darul Ulum hanya merupakan sekumpulan anak-anak yang belajar mengaji di langgar Baiturahman yang diasuh oleh Drs.KH.Masrani Murdi. Kemudian karena jumlah anak yang belajar semakin banyak maka disarankan dibuatkan tempat khusus bagi anak-anak yang belajar tersebut, maka pada tanggal 12 Mei 1986 Bapak H.Ratiyan Siswo memberikan bantuan dan tanah seluas $11 \mathrm{M}$ x $16 \mathrm{M}$ untuk pembuatan gedung belajar sampai sekarang lembaga pendidikan di bawah naungan Yayasan Pendidikan Islam Pondok Pesantren Darul Ulum telah mempunyai 6 lembaga pendidikan yaitu : 1. Madrasah Ibtidaiyah Darul Ulum 2. Madrasah Tsanawiyah Darul Ulum 3. Madrsah Aliyah Darul Ulum 4. Madrasah Diniyah Salafiyah Thabaqah Ula Darul Ulum. 5. Madrasah Diniyah Salafiyah Thabaqah Wustha Darul Ulum. 6. Madrasah Diniyah Salafiyah Thabaqah Ulya Darul Ulum. 
Meraih prestasi memang bukanlah perkara yang mudah. Untuk menjadi seseorang yang berprestasi dibutuhkan keyakinan, kerja keras bahkan pengorbanan. Di bidang apapun itu, baik dalam sekolah, pekerjaan ataupun menjadi ibu rumah tangga. Intinya jangan setengah-setengah dalam mengerjakan sesuatu. Tekuni, maka akan memperoleh hasil yang memusakan. Motivasi adalah salah satu komponen penting dalam meraih prestasi. Dengan adanya motivasi,

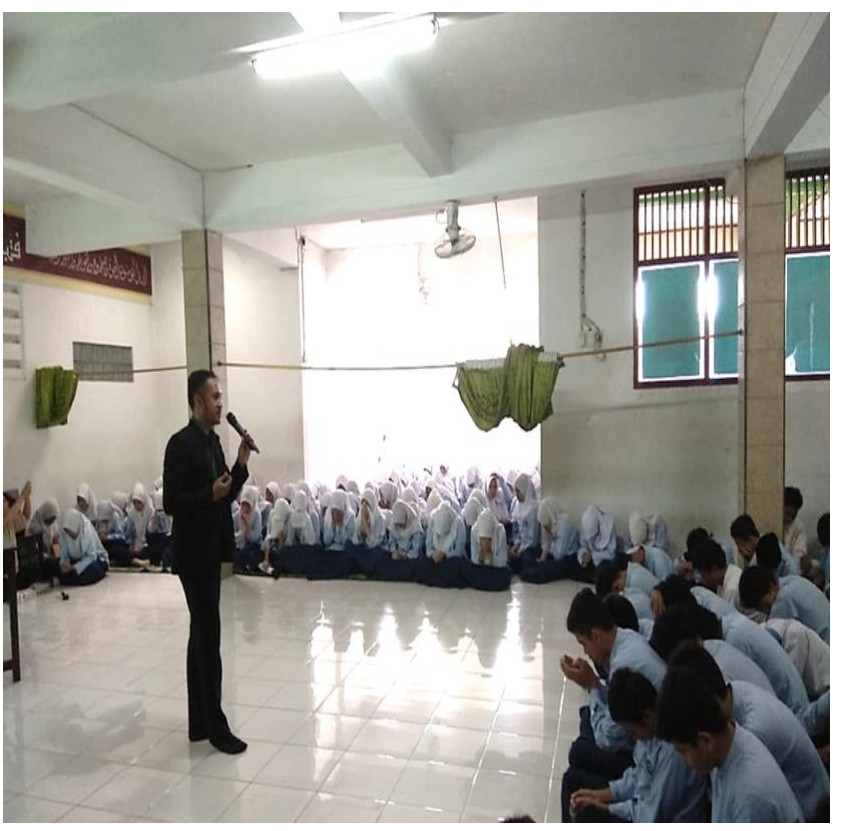
biasanya seseorang akan semakin gigih untuk meraih impiannya. Bahkan di saat down sekalipun, motivasi bisa menjadi angin segar pembangkit semangat. Motivasi sendiri ada banyak macamnya dan bisa diperoleh dari manapun. Misalnya saja dengan membaca qoutes atau kitab suci. Selain itu, perhatian dari orang-orang terdekat juga bisa menjadi motivasi untuk diri kita.

Jika kita ingin meraih prestasi dalam hidup ini, maka singkirkan perasaan ragu terlebih dahulu. Ragu-ragu hanya akan membuat pikiran stuck di satu hal saja. Cobalah bersikap berani, keluar dari zona nyaman dan hilangkan ketakutan. Jika tidak mencobanya maka selamanya berada dalam keragu-raguan. So, just try to be brave!

\section{METODE PELAKSANAAN KEGIATAN}

Metode pelaksanaan dilakukan melalui metode klasikal dengan pendekatan diskusi/tanya jawab dan simulasi dengan maksud agar materi dapat diterima oleh peserta dengan baik. Bimbingan/konsultasi dilakukan baik melalui satu sesi pertemuan terakhir.

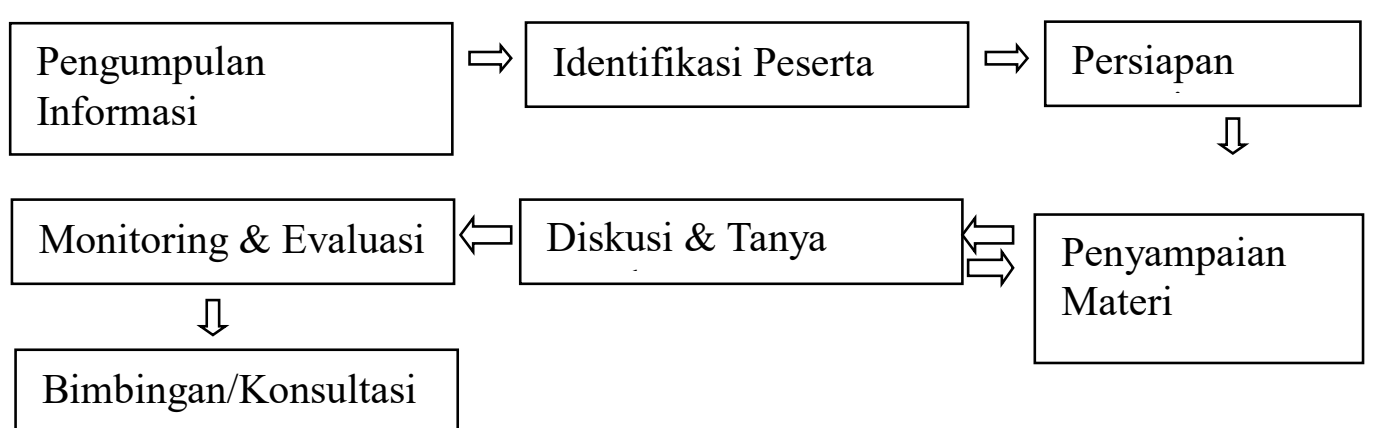




\section{HASIL DAN PEMBAHASAN}

Jalan yang harus kita lewati untuk meraih prestasi memang tidaklah mudah. Akan ada banyak kerikil, batu, lika-liku dan gangguan lainnya yang akan terus menghadang, fokuslah pada tujuan, segala macam hal yang terorganisir dan terencana pasti akan berjalan lebih baik. Maka itu, rencanakanlah semua tujuan hidup secara rinci. Tidak ada hal yang terlalu sulit untuk dicapai. Tidak ada sesuatu yang mustahil jika Kita mau berusaha. Cobalah untuk berpikir besar. Dengan berpikiran terbuka dan jauh melebihi orang-orang lain maka kita bisa menjadi sosok yang berprestasi gemilang.

Seperti kata pepatah "kegagalan bukanlah akhir dari dunia". Di saat kita melakukan sesuatu dan ternyata hasilnya tak sesuai harapan, maka katakan pada dirimu "Its okay! We can try it again". Prestasi bukan tentang apa yang kita peroleh, tapi sejauh mana kita dapat mempertahankan sesuatu yang telah kita perjuangkan tersebut setiap masalah akan membuat seseorang memperoleh pengalaman baru, yang di dalamnya terdapat berbagai peluang untuk lebih maju, berkembang dan naik kelas.

Adapun kata kunci belajar dari kesalahan adalah beranilah menanggung risiko terburuk dari apa yang kita kerjakan. Masa remaja adalah usia dimana mereka menjadi lebih acuh, cuek dan hanya fokus terhadap hal-hal tertentu di hidupnya. Remaja masa kini lebih sering bersama ponselnya daripada berinteraksi dengan orang secara langsung. Mereka lebih suka menghabiskan waktu bersama dengan teman-teman sebayanya daripada dengan orangtua. Remaja perlu tahu kapan waktu untuk asik dengan ponselnya dan kapan waktu untuk meletakkan ponsel dan fokus terhadap hal lain, misalnya saat makan bersama atau saat bertamu.

Penting belajar bagaimana cara berjabat tangan, body-gesture, cara menatap, dan tentunya cara bicara. Jangan memotong saat orang lain sedang berbicara, terutama kepada mereka yang lebih tua. Gunakan bahasa yang lebih formal seperti penggunaan 'saya' dan bukan 'aku', 'tidak' dan bukan 'nggak', atau 'terima kasih' dan bukan 'makasih'. Etika berbicara dengan orang yang lebih tua sangat dijunjung tinggi terutama di negara-negara bagian Asia. Kebudayaan dan norma sosial yang masih kental membuat etika ini sangat penting untuk dipelajari bagi anak - anak dan remaja.

Setiap anak mungkin akan memiliki pemahaman yang berbeda mengenai bagaimana mereka akan menerapkan pola perilaku dari ajaran etika dan sopan santun yang diberikan kepadanya. Namun, yang terpenting adalah pemahaman mereka mengenai mengapa menjadi sopan itu penting. Ada baiknya jika ajaran tersebut tidak selalu diberikan dengan cara bentuk perintah atau arahan yang terlalu keras. Diskusi dan cerminan diri dari orangtua juga tidak kalah penting untuk menumbuhkan perilaku sopan santun dan tatakrama. 


\begin{abstract}
KESIMPULAN DAN SARAN
Hasil kegiatan ini menjadikan para peserta dapat menyusun strategi untuk meraih prestasi dengan cara cerdas tanpa melupakan etika dan kesopanan, munculnya kesadaran akan masa depan yang baik, kehidupan yang layak yang mempunyai integritas tinggi, untuk menghadapai masa depan yang terus berkembang tanpa mengabaikan tata krama dan sifat ketimuran.
\end{abstract}

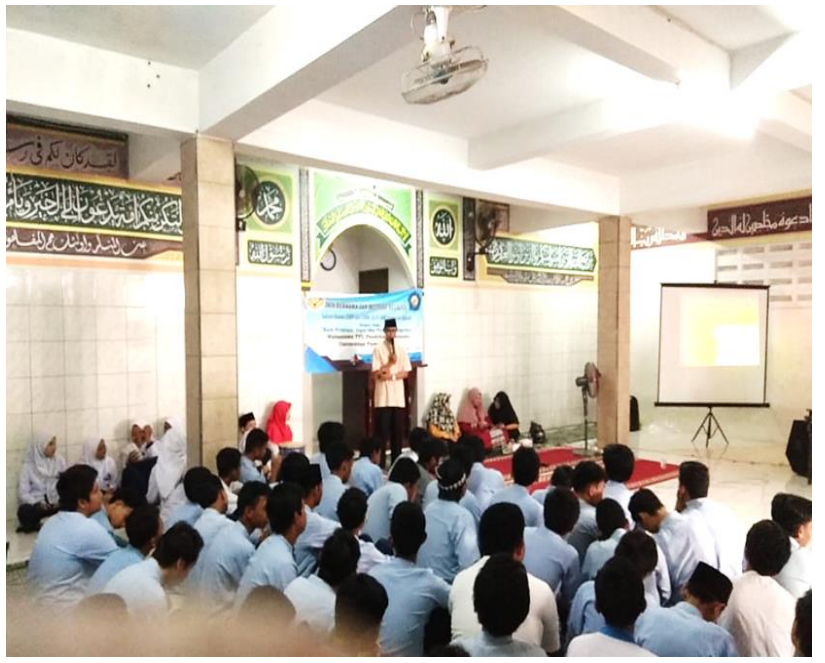

\title{
DAFTAR PUSTAKA
}

Hermawati, R., \& Susanti, N. (2018). Penyuluhan Pendidikan Karakter Bagi Anak-Anak Desa Bojong Menteng-Banten. Jurnal Pengabdian Dharma Laksana, 1(1).

Maddinsyah, A. M., Kustini, E., \& Syakhrial, S. (2018). Penyuluhan Manajemen Pemanfaatan Sumber Daya Alam Untuk Meningkatkan Perekonomian Keluarga Kampung Ciboleger Lebak-Banten. Jurnal Pengabdian Dharma Laksana, 1(1).

Maddinsyah, A., Fauzi, I., \& Barsah, A. (2019). Peran Teknologi Dalam Mengembangkan Potensi Diri Bagi Santri Di Yayasan Pembangunan Masyarakat Sejahtera Kelurahan Kedaung Pamulang Tangerang SelatanBanten. Jurnal Pengabdian Dharma Laksana, 1(2), 259-266.

Sunarsi, D., \& Asmalah, L. (2018). Pelatihan Manajemen Pengembangan Diri Bagi Penerima Beasiswa RZIS UGM Dan Dompet Shalahuddin Jogjakarta. Jurnal Pengabdian Dharma Laksana, 1(1). 


\section{PANDUAN SINGKAT BAGI PENULIS JURNAL DHARMA LAKSANA}

Panduan penulisan ini dimaksudkan untuk menyeragamkan bentuk penulisan karya ilmiah yang dikirim penulis ke redaksi Jurnal Jenius, dengan panduan penulisan sebagai berikut :

1. Naskah ditulis dalam Bahasa Indonesia dengan Abstrak Bahasa Indonesia atau Bahasa Inggris dalam bentuk Font 12" dengan ukuran 1 Spasi dengan intisari tidak lebih dari 250 kata disertai 3 atau 4 kata kunci (keyword).

Naskah berupa Softcopy program MS maksimal 10 Halaman termasuk tabel dan gambar, spasi 1.

2. Sistematika penulisan disusun dengan urutan sebagai berikut :

a) Judul, nama dan alamat email penulis/peneliti tunggal.

b) Abstrak dan intisari, keyword dan kata kunci.

c) Batang Tubuh :

1). Pendahuluan, termasuk didalamnya intisari permasalahan

2). Perumusan Masalah

3). Tujuan Penelitian

4). Aplikasi

5) Penutup

6) Daftar Pustaka atau Referensi

7) Seluruh isi tersebut di buat dengan 1 kolom

3. Judul ditulis dalam bentuk font Times New Roman 12" dengan huruf besar kecil dicetak tebal dan ditempatkan ditengah halaman,, serta tidak lebih dari 18 kata.

4. Tulisan karya ilmiah dalam bentuk font Times New Roman 12" dengan ukuran spasi 1,0 spasi dalam bentuk kolom.

5. Gambar diberi nomor dan keterangan, sedangkan tabel diberi nomor dan keterangan diatasnya.

6. Penulisan persamaan matematika yang terdapat pada halaman naskah hendaknya menggunakan equation editor.

7. Daftar pustaka hanya memuat literature yang dirujuk dalam keterangan dan dicantumkan pada bagian akhir naskah dilakukan dengan memberikan nomor.

8. Margin atas dan kiri $4 \mathrm{~cm}$, kanan dan bawah $3 \mathrm{~cm}$, dan ukuran kertas A4.

9. Dokumentasi Foto kegiatan maksimal 3. 